\title{
ANALISIS KINERJA KEUANGAN PERUSAHAAN TELEKOMUNIKASI YANG TERCATAT DI BURSA EFEK INDONESIA
}

\author{
Rezky Rahman Repon \\ Department of Management FEB UMM \\ E-mail : rezrahman92@gmail.com
}

\begin{abstract}
This research is descriptive nature of case study research analytical tool used to determine and analyze the financial performance of telecommunications companies listing in BEI using EVA analysis. Assessment of financial performance is measured with the provision that if $E V A \geq 0$, then provide economic value added to the company , if EVA $\leq 0$, then it does not give the company's.EconomicValueAdded.Based on the analysis of financial performance of telecommunications companies listed in Indonesia Stock Exchange fluctuated, In 2010 PT XL Xiata Tbk and PT Inovisi Infrcom tbk give Economic Value Added. In 2011, PT XL Xiata Tbk, PT Indosat Tbk, and PT Infracom Tbk, and PT Telekomunikasi Indonesia Tbk otherwise provide Economic Value Added and the year in 2012 Infracom PT Tbk and PT Indosat Tbkotherwise provide Economic Value Added ( EVA) $\geq 0$.Telecommunications companies that provide the greatest economic value added in 2011 was PT Telekomunikasi Indonesia tbk Based on the above conclusions, the authors recognize that these results are still far from perfect, due to the limitations of both the data and the object of research, because it is necessary for other researchers conducted research on EVA by using a longer period of study or research use another object.
\end{abstract}

Keywords: Economic Value Added, Financial Performance, telecommunication Companies

\section{PENDAHULUAN}

Perkembangan smartphone di Indonesia ini sangat menarik diikuti yang kini telah di lengkapi dengan fitur dan aplikasi unggulan salah satunya dengan adanya fasilitas internet di dalam smartphone. Pasalnya, pengguna Internet di sini mayoritas mengakses melalui ponsel. Hal itu terungkap dari presentasi yang dibawakan oleh Regional Director
Effective Measure untuk Asia Tenggara, Russell Conrad, pada acara panel diskusi Effective Measure - PPPI, di Jakarta, Jumat 1 April 2011. Hasil riset Effective Measure, firma yang memiliki spesialisasi dalam pengukuran statistik web, sebanyak 61,88 persen dari pengguna Internet Indonesia mengakses melalui ponsel dan 38,12 persen lainnya mengakses 
Internet bukan dari ponsel. mengalami perubahan yang sangat (news.viva.co.id)

\section{Persaingan Industri}

Telekomunikasi nasional saat ini ditandai dengan mulai menguatnya tiga tren utama, yaitu evolusi platform jejaring sosial, mulai mewabahnya telepon seluler (ponsel) pintar, dan menguatnya posisi tawar konsumen. Derasnya ketiga arus tren tersebut diyakini memberikan warna dan bentuk tersendiri pada industri telekomunikasi di Tanah Air. Analis emiten sektor telekomunikasi dari Ekokapital Securities Cece Ridwanullah mengatakan, operator telekomunikasi harus terus meningkatkan kinerjanya. Pasalnya, jumlah pengguna layanan data ini ke depan akan semakin meningkat seiring dengan tingkat kebutuhan mobile lifestyle terhadap internet dan maraknya pengguna ponsel pintar. (www.icc-expo.com). Direktur Utama Telkomsel Sarwoto Atmosutarno mengatakan bahwa, industri telekomunikasi di Indonesia akan bisa terus berkembang. Jumlah penduduk yang mencapai 240 juta jiwa dengan pendapatan per kapita menembus US $\$ 3.000$ di mana $56,5 \%$ penduduk mengeluarkan belanja US\$45 perhari untuk pasar telekomunikasi di tanah air ini sangat menjanjikan. (www.kabarbisnis.com).

BerdasarkanUU No 36 Tahun 1999 Pasal 10 ayat 1 tentang telekomunikasi pelaksanaan perdagangan telekomunikasi di Indonesia tidak lagi monopoli tetapi mengarah ke persaingan bebas. Peraturan tersebut membuat struktur telekomunikasi di Indonesia mulai mendasar. Persaingan dagang sektor telekomunikasi secara langsung maupun tidak langsung akan berimbas pada penjualan perusahaan telekomunikasi.

Tabel 1 menunjukan dari setiap tahunnya perusahaan telekomunikasi mengalami peningkatan dalam penjualannya, kecuali PT Bakrie Telecom, dan untuk Laba Bersih Usaha. Seluruh Perusahaan Telekomunikasi berfluktuasi ini dikarenakan adanya beban usaha pada perusahaan. Kinerja atau prestasi perusahaan mengacu pada hasil dari banyakkeputusan individual yang dibuat secara terus-menerus oleh manajemen, oleh karena itu untuk menilai prestasi perusahaan perlu dilibatkan suatu analisis terhadap efek keuangannya.

Salah satu manfaat pengukuran kinerja yaitu untuk mengukur prestasi yang dicapai oleh suatu organisasi dalam suatu periode tertentu yang mencerminkan tingkat keberhasilan pelaksanaan kegiatannya.

Pengukuran kinerja untuk mengetahui tingkat stabilitas usaha, yaitu kemampuan perusahaan untuk melakukan usahanya dengan stabil, yang diukur dengan mempertimbangkan kemampuan perusahaan untuk membayar beban bunga atas hutang-hutangnya termasuk membayar kembali pokok hutangnya tepat pada waktunya serta kemampuan membayar deviden secara teratur kepada para pemegang saham tanpa mengalami hambatan atau krisis keuangan. 
Tabel 1. Data Penjualan dan Laba Bersih Perusahaan Telekomunikasi (Dalam Jutaan Rupiah)

\begin{tabular}{|c|c|c|c|c|c|}
\hline Tahun & Perusahaan & Penjualan & $\begin{array}{c}\text { Persen } \\
(\%)\end{array}$ & $\begin{array}{l}\text { Laba } \\
\text { Usaha }\end{array}$ & $\begin{array}{c}\text { Persen } \\
(\%)\end{array}$ \\
\hline \multirow{6}{*}{2010} & PT. Bakrie Telecom tbk & 3.447 .118 & - & -190.000 & - \\
\hline & PT. XL-XIATA tbk & 17.057 .760 & - & 4.984 .925 & - \\
\hline & PT. Smartfren Telecom tbk & 376.511 & - & -867.386 & - \\
\hline & PT. Inovisi Infracom tbk & 330.502 & - & 101.426 & - \\
\hline & PT. Indosat tbk & 19.796.515 & - & 3.473 .944 & - \\
\hline & $\begin{array}{l}\text { PT. Telekomunikasi } \\
\text { Indonesia tbk }\end{array}$ & 68.629 .181 & - & 22.787 .636 & - \\
\hline \multirow{6}{*}{2011} & PT. Bakrie Telecom tbk & 3.195 .451 & 24,48 & -174.009 & $-8,42$ \\
\hline & PT. XL-XIATA tbk & 18.260 .144 & 7,05 & 4.443 .363 & 10,86 \\
\hline & PT. Smartfren Telecom tbk & 954.331 & 153,4 & -2.221 .628 & $\overline{-}^{-}$ \\
\hline & PT. Inovisi Infracom tbk & 544.257 & 64,68 & 387.149 & 281,70 \\
\hline & PT. Indosat tbk & 20.259 .292 & 2,34 & 3.164 .309 & $-8,91$ \\
\hline & $\begin{array}{l}\text { PT. Telekomunikasi } \\
\text { Indonesia tbk }\end{array}$ & 71.253 .000 & 3,82 & 21.958 .000 & $-, 3,64$ \\
\hline \multirow{6}{*}{2012} & PT. Bakrie Telecom tbk & 2.973 .613 & $-8,88$ & -500.373 & 187,56 \\
\hline & PT. XL-XIATA tbk & 18.260 .144 & 6,94 & 4.352 .463 & 4,35 \\
\hline & PT. Smartfren Telecom tbk & 1.649 .165 & 6,94 & -1.602 .597 & $-27,86$ \\
\hline & PT. Inovisi Infracom tbk & 1.234 .860 & 126 & 460.051 & 18,83 \\
\hline & PT. Indosat tbk & 22.418 .812 & 10,66 & 3.190 .023 & \multirow{2}{*}{$\begin{array}{c}0,81 \\
17,03\end{array}$} \\
\hline & $\begin{array}{l}\text { PT. Telekomunikasi } \\
\text { Indonesia tbk }\end{array}$ & 77.143 .000 & 8,27 & 25.698 .000 & \\
\hline
\end{tabular}

Sumber: Bursa Efek Indonesia (BEI)

Kondisi perusahaan yang harus selalu ditinjau dapat dilakukan dengan menganalisa laporan keuangan sendiri yang pada umumnya terdiri dari laporan neraca dan laporan laba/rugi. Laporan neraca dan laba/rugi ini bersifat saling berkaitan dan melengkapi. Neraca menggambarkan keadaan keuangan suatu perusahaan pada periode tertentu, sedangkan laporan laba rugi menunjukkan hasil usaha dan biaya-biaya selama periode akuntansi. Laporan keuangan tersebut akan lebih informatif dan bermanfaat maka pihak-pihak yang berkepentingan terhadap informasi keuangan harus melakukan analisa terlebih dahulu.

Penilaian kinerja dengan menggunakan pendekatan EVA merupakan sistem yang disesuaikan dengan manajemen keuangan karena bertitik berat pada nilai bagi investor. Menggunakan pendekatan EVA, para manajer akan berpikir dan bertindak seperti halnya pemegang saham yaitu memilih investasi yang 
memaksimumkan tingkat pengembalian dan meminimumkan tingkat biaya modal sehingga nilai perusahaan dapat dimaksimumkan. Alasan pemilihan obyek penelitian pada perusahaan telekomunikasi yang tercatat di Bursa Efek Indonesia, karena penjualan perusahaan telekomunikasi meningkat dari tahun ke tahun danberdasarkan UU No 36 Tahun 1999 tentang telekomunikasi pelaksanaan persaingan secara bebas yang secara langsung maupun tidak langsung akan berimbas pada penjualan dan laba usaha perusahaan telekomunikasi.

Berdasarkan uraian latar belakang di atas, maka menarik dilakukan penelitian dengan judul "analisis kinerja keuangan perusahaan telekomunikasi yang tercatat di bursa efek indonesia". Berdasarkan latar belakang yang telah diuraikan diatas, maka rumusan masalah yang diambil adalah 1) Apakah kinerja keuangan perusahaan Telekomunikasi yang tercatat di Bursa Efek Indonesia (BEI) memberikan nilai tambah ?2) Perusahaan telekomunikasi manakah yang memberikan Economic Value Added paling besar?

\section{TINJAUAN PUSTAKA}

Peneliti terdahulu yang digunakan adalah adalah penelitian yang dilakukan olehSony siswanto (2012) dengan tujuan penelitian mengetahui Evaluasi kinerja keuangan pada perusahaan sektor telekomunikasi yang tercatat di bursa efek jakarta (BEJ). Alat analisis yang digunakan dalam penelitian ini adalah Economic Value Added (EVA). Munawir (2007:9) kinerja merupakan prestasi yang ingin dicapai dalam periode tertentu yang mencerminkan tingkat kesehatan dibidang keuangan yang ditunjukkan melalui laporan keuangan perusahaan.

Metode EVA pertama kali dicetuskan oleh Stern Steward Management Services perusahaan konsultasi di Amerika Serikat pada tahun 1991. Mereka mengembangkan suatu konsep penilaian kinerja yang dapat menciptakan nilai bagi pemilik perusahaan. Warsono (2003) EVA adalah suatu estimasi laba ekonomis yang benar atas suatu bisnis selama tahun tertentu. Hal ini berbeda secara substansial jika dibandingkan dengan laba akuntansi.

EVA mempresentasikan pendapatan residual yang tersisa setelah biaya peluang (opportunity cost) dari semua modal yang ada. Ini tentu beda dengan laba akuntansi yang tidak memasukkan unsur biaya modal ekuitas. Warsono (2003:48) rumus dasar dari EVA adalah sebagai berikut:

EVA = Laba Operasi Setelah Pajak Biaya dari Semua Modal $=($ Pendapatan Penjualan - Biaya-Biaya Operasi Pajak) - (Pasokan Modal - Total Biaya Modal)

Adapun kerangka pikir dapat diuraikan pada gambar 1 . 


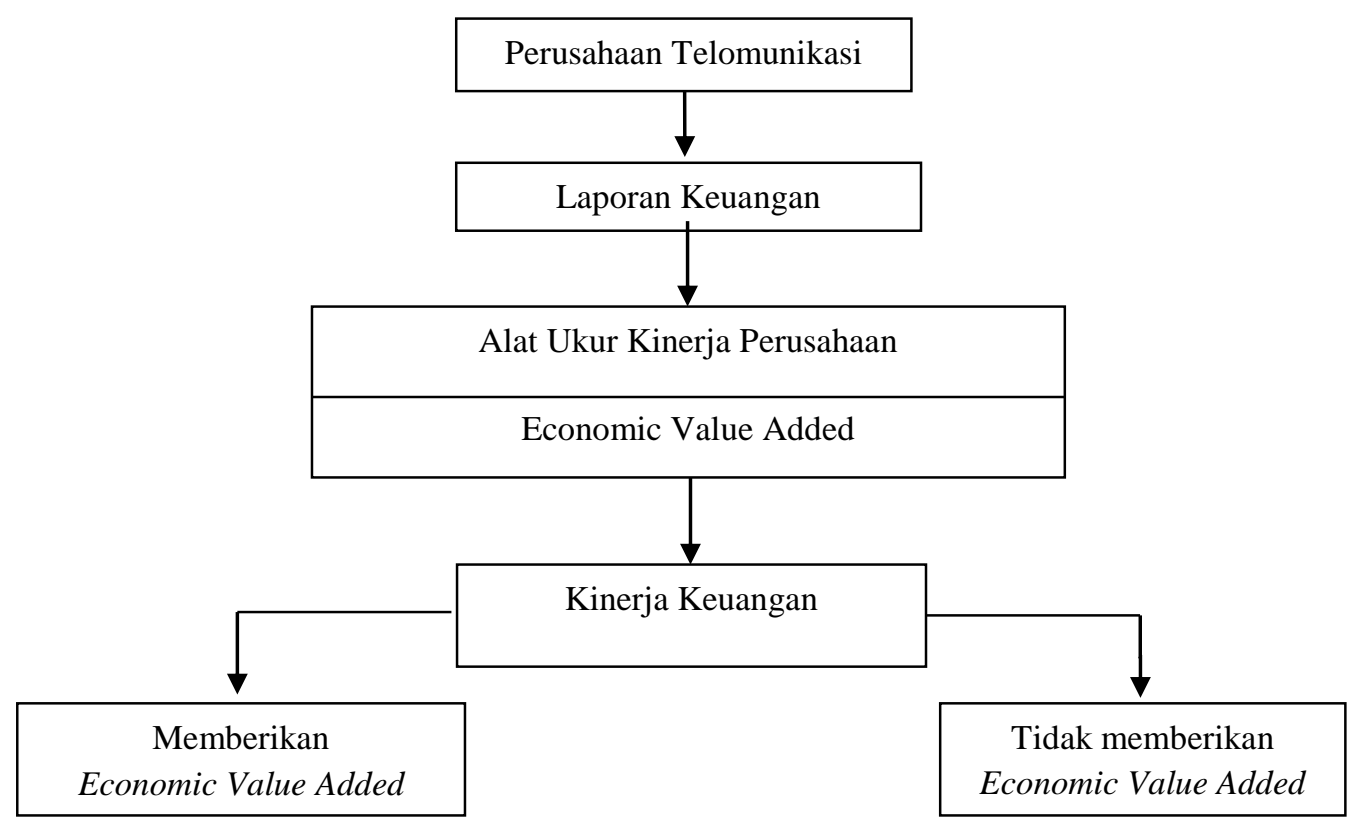

Gambar 1. Kerangka Pikir

Hipotesis yang diajukan dalam penelitian ini adalah sebagai berikut:

1) H1Perusahaan telekomunikasi yang terdaftar di Bursa Efek Indonesia memberikan Economic Value Added. 2) $\mathrm{H} 2$ Perusahaan Telekomunikasi Indonesia Tbk, merupakan perusahaan yang memberikan Economic Value Added paling besar diantara perusahaaan - perusahaan telekomunikasi yang lain.

\section{METODE PENELITIAN}

Jenis penelitian ini adalah penelitian deskriptif. jenisdata sekunder. Sumber data tersebut diperoleh dari data laporan keuangan perusahaan sektor Telekomunikasi yang tercatat di Bursa Efek Indonesia dari periode 2010 sampai 2012. Teknik pengumpulan data dengan mempelajari dan menggunakan data yang telah dibuat oleh perusahaan sektor telekomunikasi yang tercatat di Bursa Efeik Indonesia tahun 2010 sampai 2012. Selanjutnya data tersebut dipelajari serta diklasifikasikan kemudian dianalisis. Populasi dalam penelitian ini adalah perusahaan sektor telekomunikasi yang tercatat di Bursa Efek Indonesia (BEI). Teknik sampling yang digunakan dalam penelitian ini adalah metode sensus, yaitu merupakan metode yang mempertimbangkan untuk menginvestigasi seluruh elemen populasi yang dimaksudkan untuk menjelaskan karakteristik setiap elemen dari setiap populasi.

Dalam penelitian ini yaitu berjumlah 6 perusahaan telekomuikasi yang tercatat di Bursa Efek Indonesia (BEI). Definisi operasional variable adalah 1) Economic Value Added (EVA) 2) Biaya modal utang (Cost of Debt) 3) Biaya laba ditahan 4) Weighted Average Cost of Capital (Biaya Modal Rata-rata Tertimbang/ WACC) 5) Biaya Modal 6) 
Menghitung Laba Operasi Setelah Pajak.

Analisis data dengan menggunakan, Menghitung biaya modal utang (Cost of Debt), Menghitung Biaya Laba Ditahan, Menghitung struktur permodalan berbasis pasar, Menghitung Biaya modal Rata-Rata Tertimbang, Biaya Modal, Menghitung Laba Operasi Setelah Pajak, Menghitung EVA (Economic Value Added). Uji Hipotesis sebagai berikut: 1) H1 Jika EVA $\geq 0$, (hipotesis diterima) maka perusahaan dinyatakan memberikan Economic Value Added ke dalam perusahaan karena laba yang tersedia bisa memenuhi harapan investor, jika EVA $\leq 0, \quad$ (hipotesis ditolak) perusahaan tidak memberikan Economic Value Added ke dalam perusahaan karena laba yang tersedia tidak bisa memenuhi harapan investor. 2) $\mathrm{H} 2$ Jika $\mathrm{EVA} \geq 0$ (hipotesis diterima) sehingga PT Telekomunikasi Indonesia Tbk merupakan perusahaan yang memberikan Economic Value Added karena laba yang tersedia bisa memenuhi harapan investor, daripada perusahaan telekomunikasi lainnya yang tercatat di Bursa Efek Indonesia.

\section{HASIL PENELITIAN DAN PEMBAHASAN}

Populasi yang digunakan sebagai obyek penelitian adalah perusahaan sektor telekomunikasi yang tercatat di Bursa Efek Indonesia. Daftar perusahaan yang tercatat di BEI yaitu:
Tabel 2. Perusahaan Telekomunikasi yang Tercatat Di Bursa Efek Indonesia

\begin{tabular}{ll}
\hline No & Perusahaan Telekomunikasi \\
\hline 1 & PT Bakrie Telecom Tbk \\
2 & PT XL-Xiata Tbk \\
3 & PT Smartfren Telecom Tbk \\
4 & PT Inovisi Infracom Tbk \\
5 & PT Indosat Tbk \\
6 & PT Telekomunikasi Indonesia \\
& tbk \\
Sumber: $\underline{w w w . d u n i a i n v e s t a s i . c o m ~}$
\end{tabular}

Tabel 3 Menunjukan Bahwa biaya Modal Perusahaan Telekomunikasi dari tahun ke tahun berfluktuasi, karena biaya modal merupakan tingkat hasil atas investasi total perusahaan yang menghasilkan tingkat pengembalian yang diisyaratkan dari semua sumber pembelanjaannya. Berikut ini adalah cara menghitung Economic Value Added (EVA).

EVA = Laba Operasi Setelah Pajak Biaya dari Semua Modal.

Jika EVA $\geq 0$, maka perusahaan dinyatakan sehat dan perusahaan telah memberi Economic Value Added ke dalam perusahaan karena laba yang tersedia bisa memenuhi harapan investor, dan jika EVA $\leq 0$, maka perusahaan dinyatakan tidak sehat dan perusahaan tidak memberikan Economic Value Added ke dalam perusahaan karena laba yang tersedia tidak bisa memenuhi harapan investor. 
Tabel 3. Perhitungan Biaya modal Rata-Rata Tertimbang (WACC) Perusahaan

Telekomunikasi

\begin{tabular}{|c|c|c|c|c|c|c|}
\hline Tahun & Perusahaan & Wd & $\mathrm{Ki}$ & Ws & Ks & WACC \\
\hline \multirow{6}{*}{2010} & PT. Bakrie Telecom tbk & 0,5096 & $6,03 \%$ & 0,4904 & $34 \%$ & $4,74 \%$ \\
\hline & PT. XL-XIATA tbk & 0,4837 & $8,37 \%$ & 0,5163 & $64,5 \%$ & $7,38 \%$ \\
\hline & $\begin{array}{l}\text { PT. Smartfren Telecom } \\
\text { tbk }\end{array}$ & 1,8629 & $0,00 \%$ & 0,8629 & $6,40 \%$ & $3,20 \%$ \\
\hline & PT. Inovisi Infracom tbk & 0,0154 & $9,35 \%$ & 0,9846 & $9,30 \%$ & $9,36 \%$ \\
\hline & PT. Indosat tbk & 0,5632 & $1,64 \%$ & 0,4368 & $17,96 \%$ & $8,85 \%$ \\
\hline & $\begin{array}{l}\text { PT. Telekomunikasi } \\
\text { Indonesia tbk }\end{array}$ & 0,2951 & $6,05 \%$ & 0,7049 & $27,84 \%$ & $27,84 \%$ \\
\hline \multirow{6}{*}{2011} & PT. Bakrie Telecom tbk & 0,5281 & $0,00 \%$ & 0,4719 & $33 \%$ & $1,56 \%$ \\
\hline & PT. XL-XIATA tbk & 0,3899 & $6,32 \%$ & 0,6101 & $10,94 \%$ & $10,94 \%$ \\
\hline & $\begin{array}{l}\text { PT. Smartfren Telecom } \\
\text { tbk }\end{array}$ & 0,6446 & $0,00 \%$ & 0,3554 & $2,30 \%$ & $8,20 \%$ \\
\hline & PT. Inovisi Infracom tbk & 0,1573 & $2,38 \%$ & 0,8427 & $4,10 \%$ & $3,83 \%$ \\
\hline & PT. Indosat tbk & 0,5463 & $2,06 \%$ & 0,4537 & $6,16 \%$ & $1,72 \%$ \\
\hline & $\begin{array}{l}\text { PT. Telekomunikasi } \\
\text { Indonesia tbk }\end{array}$ & 0,2459 & $6,11 \%$ & 0,7541 & $9,49 \%$ & $8,66 \%$ \\
\hline \multirow{6}{*}{2012} & PT. Bakrie Telecom tbk & 0,7349 & $0,00 \%$ & 0,2651 & $79 \%$ & $2,09 \%$ \\
\hline & PT. XL-XIATA tbk & 0,4247 & $5,08 \%$ & 0,5753 & $11,59 \%$ & $11,59 \%$ \\
\hline & $\begin{array}{l}\text { PT. Smartfren Telecom } \\
\text { tbk }\end{array}$ & 0,5593 & $0,00 \%$ & 0,4407 & $18,60 \%$ & $8,20 \%$ \\
\hline & PT. Inovisi Infracom tbk & 0,0164 & $32,13 \%$ & 0,9836 & $4,08 \%$ & 3,46 \\
\hline & PT. Indosat tbk & 0,5613 & $2,20 \%$ & 0,4387 & $10,66 \%$ & $3,44 \%$ \\
\hline & $\begin{array}{l}\text { PT. Telekomunikasi } \\
\text { Indonesia tbk }\end{array}$ & 0,2324 & $7,68 \%$ & 0,7676 & $47,39 \%$ & $38,16 \%$ \\
\hline
\end{tabular}

Dari tabel 3 Menunjukan bahwa Economic Value added (EVA) perusahaan telekomunikasi dari tahun ke tahun berfluktuasi, karena Economic Value Added (EVA) adalah suatu estimasi laba ekonomis yang benar atas suatu bisnis selama tahun tertentu serta mempresentasikan pendapatan residual yang tersisa setelah biaya peluang (opportunity cost) dari semua modal yang ada.

Perusahaan Telekomunikasi yang memberikan Economic Value
Added paling besar yaitu pada tahun 2011 adalah PT Telekomunikasi Indonesia tbk yaitu dengan jumlah 8.468.711.701.429 dan Perusahaan Telekomunikasi yang memberikan Economic Value Addedpaling kecil adalah PT Inovisi Infracom Tbk yaitu dengan jumlah 297.935.165.188. Perusahaan Telekomunikasi yang memberikan Economic Value Added paling besar pada tahun 2012 adalah PT Indosat tbk yaitu sebesar 1.956.620.264.000. 
Tabel 4. Perhitungan Biaya Modal Perusahaan Telekomunikasi (Dalam Rupiah)

\begin{tabular}{|c|c|c|}
\hline Tahun & Perusahaan & Biaya Modal \\
\hline \multirow{6}{*}{2010} & PT. Bakrie Telecom tbk & 502.121 .735 .433 \\
\hline & PT. XL-XIATA tbk & 1.674 .392 .702 .400 \\
\hline & PT. Smartfren Telecom tbk & -4.430 .224 .704 \\
\hline & PT. Inovisi Infracom tbk & 87.852 .065 .940 \\
\hline & PT. Indosat tbk & 3.655 .065 .841 .500 \\
\hline & $\begin{array}{l}\text { PT. Telekomunikasi } \\
\text { Indonesia tbk }\end{array}$ & 22.279.795.200.000 \\
\hline \multirow{6}{*}{2011} & PT. Bakrie Telecom tbk & 144.414 .710 .882 \\
\hline & PT. XL-XIATA tbk & 2.455.993.434.370 \\
\hline & PT. Smartfren Telecom tbk & 75.414 .949 .993 \\
\hline & PT. Inovisi Infracom tbk & 82.893 .665 .710 \\
\hline & PT. Indosat tbk & -709.757 .054 .000 \\
\hline & $\begin{array}{l}\text { PT. Telekomunikasi } \\
\text { Indonesia tbk }\end{array}$ & 7.001.288.298.571 \\
\hline \multirow{6}{*}{2012} & PT. Bakrie Telecom tbk & 129.120 .198 .118 \\
\hline & PT. XL-XIATA tbk & 3.096.350.673.100 \\
\hline & PT. Smartfren Telecom tbk & 927.099 .921 .132 \\
\hline & PT. Inovisi Infracom tbk & -85.544 .800 .950 \\
\hline & PT. Indosat tbk & -1.520 .800 .264 .000 \\
\hline & $\begin{array}{l}\text { PT. Telekomunikasi } \\
\text { Indonesia tbk }\end{array}$ & 33.300 .924 .282 .720 \\
\hline
\end{tabular}

Sumber: Data Diolah 2013

Perusahaan Telekomunikasi yang memberikan Economic Value Added (EVA) terkecil adalah PT Inovisi Infracom Tbk yaitu sebesar 541.442.268.732. Berdasarkan pendekatan analisis Cross Section menunjukan bahwa dari seluruh perusahaan telekomunikasi yang memberikan Economic Value Added lebih besar pada tahun 2011 yaitu PT Telekomunikasi Indonesia tbk jika dibandingkan dengan perusahaan telekomunikasi lainnya.
Teori yang terkait dengan analisis Economic Value Added (EVA) menurut warsono (48:2003) adalah suatu estimasi laba ekonomis yang benar atas suatu bisnis selama satu tahun tertentu. Suatu perusahaan dapat menghasilkan Economic Value Added EVA pada investor dan jika Economic Value Added (EVA) maka perusahaan dinyatakan tidak memberikan Economic Value Added (EVA) terhadap investor. 
Tabel 5. Perhitungan NOPAT Perusahaan Telekomunikasi (Dalam Rupiah)

\begin{tabular}{llr}
\hline Tahun & \multicolumn{1}{c}{ Perusahaan } & \multicolumn{1}{c}{ NOPAT } \\
\hline \multirow{2}{*}{2010} & PT. Bakrie Telecom tbk & 2.891 .261 .000 .000 \\
& PT. XL-XIATA tbk & -1.401 .813 .486 .084 \\
& PT. Smartfren Telecom tbk & 124.251 .454 .439 \\
& PT. Inovisi Infracom tbk & 724.019 .000 .000 \\
& PT. Indosat tbk & 15.870 .000 .000 .000 \\
& PT. Telekomunikasi Indonesia tbk & -1.193 .108 .586 .830 \\
& PT. Bakrie Telecom tbk & 2.830 .101 .000 .000 \\
& PT. XL-XIATA tbk & -2.898 .742 .444 .436 \\
PT. Smartfren Telecom tbk & 380.828 .830 .898 \\
& PT. Inovisi Infracom tbk & 1.066 .744 .000 .000 \\
& PT. Indosat tbk & 15.470 .000 .000 .000 \\
& PT. Telekomunikasi Indonesia tbk & -3.928 .158 .579 .384 \\
& PT. Bakrie Telecom tbk & 2.764 .647 .000 .000 \\
& PT. XL-XIATA tbk & -2.060 .120 .571 .062 \\
PT. Smartfren Telecom tbk & 455.897 .467 .782 \\
PT. Inovisi Infracom tbk & 435.820 .000 .000 \\
& PT. Indosat tbk & 18.362 .000 .000 .000 \\
\hline PT. Telekomunikasi Indonesia tbk &
\end{tabular}

Sumber: Data Diolah 2013

Tabel 6 Menunjukan Bahwa

EVA Perusahaan Telekomunikasi dari tahun ke tahun berfluktuasi, karena laba operasi setelah pajak yang merupakan sejumlah laba perusahaan yang akan dihasilkan jika perusahaan tersebut tidak memiliki utang dan tidak memiliki asset finansial.

Tabel 6. Perhitungan Economic Value added (EVA) Perusahaan Telekomunikasi (Dalam Rupiah)

\begin{tabular}{|c|c|c|c|}
\hline Tahun & Perusahaan & $\begin{array}{c}\text { Economic } \\
\text { Value Added }\end{array}$ & Keterangan \\
\hline \multirow[t]{5}{*}{2010} & PT. Bakrie Telecom tbk & -438.783 & $\begin{array}{c}\text { Tidak Memberikan } \\
\text { Economic Value Added }\end{array}$ \\
\hline & PT. XL-XIATA tbk & 1.216 .868 & $\begin{array}{c}\text { Memberikan Economic } \\
\text { Value Added }\end{array}$ \\
\hline & PT. Smartfren Telecom tbk & -1.397 .383 & $\begin{array}{c}\text { Tidak Memberikan } \\
\text { Economic Value Added }\end{array}$ \\
\hline & PT. Inovisi Infracom tbk & 36.399 & $\begin{array}{c}\text { Memberikan Economic } \\
\text { Value Added }\end{array}$ \\
\hline & PT. Indosat tbk & -2.931 .046 & $\begin{array}{c}\text { Tidak Memberikan } \\
\text { Economic Value Added }\end{array}$ \\
\hline
\end{tabular}




\begin{tabular}{|c|c|c|c|}
\hline & PT. Telekomunikasi Indonesia tbk & -6.409 .795 & $\begin{array}{c}\text { Tidak Memberikan } \\
\text { Economic Value Added }\end{array}$ \\
\hline \multirow[t]{6}{*}{2011} & PT. Bakrie Telecom tbk & -1.337 .523 & $\begin{array}{l}\text { Tidak Memberikan } \\
\text { Economic Value Added }\end{array}$ \\
\hline & PT. XL-XIATA tbk & 374.107 & $\begin{array}{c}\text { Memberikan Economic } \\
\text { Value Added }\end{array}$ \\
\hline & PT. Smartfren Telecom tbk & -2.974 .157 & $\begin{array}{c}\text { Tidak Memberikan } \\
\text { Economic Value Added }\end{array}$ \\
\hline & PT. Inovisi Infracom tbk & 297.935 & $\begin{array}{c}\text { Memberikan Economic } \\
\text { Value Added }\end{array}$ \\
\hline & PT. Indosat tbk & 1.776 .501 & $\begin{array}{c}\text { Memberikan Economic } \\
\text { Value Added }\end{array}$ \\
\hline & PT. Telekomunikasi Indonesia tbk & 8.468 .711 & $\begin{array}{c}\text { Memberikan Economic } \\
\text { Value Added }\end{array}$ \\
\hline \multirow[t]{6}{*}{2012} & PT. Bakrie Telecom tbk & -4.057 .278 & $\begin{array}{c}\text { Tidak Memberikan } \\
\text { Economic Value Added }\end{array}$ \\
\hline & PT. XL-XIATA tbk & -331.703 & $\begin{array}{c}\text { Tidak Memberikan } \\
\text { Economic Value Added }\end{array}$ \\
\hline & PT. Smartfren Telecom tbk & -2.987 .220 & $\begin{array}{c}\text { Tidak Memberikan } \\
\text { Economic Value Added }\end{array}$ \\
\hline & PT. Inovisi Infracom tbk & 541.442 & $\begin{array}{c}\text { Memberikan Economic } \\
\text { Value Added }\end{array}$ \\
\hline & PT. Indosat tbk & 1.956 .620 & $\begin{array}{c}\text { Memberikan Economic } \\
\text { Value Added }\end{array}$ \\
\hline & PT. Telekomunikasi Indonesia tbk & -14.938 .924 & $\begin{array}{c}\text { Tidak Memberikan } \\
\text { Economic Value Added }\end{array}$ \\
\hline
\end{tabular}

Sumber: Data Diolah 2013

\section{SIMPULAN}

Berdasarkan analisis yang telah diuraikan sebelumnya maka dapat diambil kesimpulan bahwa kinerja keuangan perusahaan Telekomunikasi yang tercatat di Bursa Efek Indonesia (BEI) selama tahun 2010 sampai 2012 berfluktuasi. Pada tahun 2010 PT XL-Xiata Tbk dan PT Inovisi Infracom Tbk Memberikan Economic Value Added $(\mathrm{EVA} \geq 0)$.

Pada tahun 2011 perusahaan Telekomunikasi yang Memberikan Economic Value Added (EVA $\geq 0)$ yaitu PT XL-Xiata Tbk, PT Inovisi Infracom Tbk, PT Indosat tbk dan PT Telekomunikasi Indonesia tbk . Pada tahun 2012 PT Indosat tbkdan PT Inovisi Infracom Tbk. Perusahaan
Telekomunikasi yang memberikan Economic Value Added paling besar yaitu pada tahun 2011 PT Telekomunikasi Indonesia tbk yaitu sebesar 8.468.711.701.429.

\section{DAFTAR PUSTAKA}

Bringham, Eugene dan Houston, $2006 . \quad$ Dasar-Dasar Manajemen Keuangan. Edisi 11, Buku 1, Salemba Empat, Jakarta.

Hanafi, Mamduh M., 2004. Manajemen Keuangan; Edisi 2004/2005, BPFEYogyakarta, Yogyakarta. Jogiyanto. 2003. Teori Portofolio dan Analisis Investasi. Edisi Ketiga. BPFE Yogyakarta 
Kasmir. (2012). Analisis Laporan Keuangan. Jakarta : PT Raja Grafindo Persada

Munawir, S. 2007. Analisa Laporan Keuangan. Edisi Keempat. Yogyakarta: Liberty. Yogyakarta.

Samsul Mohammad. 2006. Pasar Modal dan Manajemen Portofolio; Penerbit Erlangga, Jakarta.

Sanusi, Anwar. 2011. Metodologi Penelitian Bisnis. Salemba Empat. Jakarta

Sartono, Agus. 2010. Manajemen Keuangan (Teori dan Aplikasi). BPFE: Yogyakarta.

Siswanto, 2012. Analisis Kinerja Keuangan Perusahaan Telekomunikasi Tahun 20072008. Skripsi: UMM.

Sutrisno, 2009. Manajemen Keuangan Teori, Konsep dan Aplikasi, Edisi ketujuh, penerbit BPFE-Yogyakarta.

Warsono, 2003, Manajemen Keuangan Perusahaan, Edisi Ketiga, Cetakan Pertama, Malang.

Young, S. David dan O'Byrne, Stephen F. 2001. EVA dan Manajemen Berdasarkan Nilai Panduan Praktis untuk Implementasi. Jakarta: Salemba Empat.

http://dittel.kominfo.go.id/wpcontent/uploads/2013/06/36TAHUN-1999.pdf .Diakses pada tanggal 11-10-2013

http://jakarta.okezone.com/read/2012 /12/24/54/736313/persainganketat-industritelekomunikasimakin-seru. Diakses pada tanggal 11-10-2013

http://teknologi.news.viva.co.id/news $\underline{\mathrm{read} / 212654-\text { mayoritas- }}$ netter-indonesia-akses-viaponsel. Diakses pada tanggal 11-10-2013

http://www.kabarbisnis.com/read/28 $\underline{24680}$.Diakses pada tanggal 11-10-2013

www.iccexpo.com/2011/content.php ?path=news\&go=newsslette $\underline{\text { r\&topic }=\text { PersainganOperato }}$ rTelekomunikasiMakinKeta t\&show=1 .Diakses pada tanggal 11-10-2013

http://www.duniainvestasi.com/bei/st ock/prices/stock/. Diakses pada tanggal09-11-2013 
